African J. Biol. Sci., 16 (1): 107-117 (2020)

ISSN 1687-4870

www.ajbs.journals.ekb.eg

e- ISSN 2314-5501 (online)

E.mail: aasdjournal@yahoo.com

\title{
Antischistosomal and antioxidant protective role of Carica papaya fruit extracts against Schistosoma mansoni
}

\author{
Ibrahim Aly ${ }^{1}$, Hanan Taher ${ }^{2,3^{*}}$ and Faten EL-Feky ${ }^{3}$ \\ 1-Parasitology Department, Theodor Bilharz Research Institute.Giza, Egypt
}

2- Department of Biology, College of Science, Jouf Univ., P.O. Box: 2014,Sakaka, Saudi Arabia

3- Department of Zoology, Faculty of Science, Girls Branch Al-Azhar University, Cairo, Egypt

*dr.h.taher@gmail.com

Received: July. 22, 2020; Accepted: August. 29, 2020; Available online : September 30, 2020

\section{ABSTRACT}

Schistosomiasis is a major disease of public health in human. Patterns on immune response, worm recovery, in vitro antischistosomal bioassay screening (cercaricidal killing in vitro of Schistosoma mansoni was observed). In vivo Mice were infected by injection of $100 \mathrm{~S}$. mansoni cercariae/mouse and treated by oral administration with crude extract, $\mathrm{MeOH}$, ethyl acetate (EtOAc) and butanol $(\mathrm{BuOH})$ Carica papaya fruits $(4 \mathrm{~g} / \mathrm{kg})$ start from 7 th day p.i. to the end of experiment and a treatment control of $500 \mathrm{mg} / \mathrm{kg}$ of Praziquantel. Various concentrations of plant extracts were used in cercaricidal assay. Both crude extract and EtOAc showed significant dose-dependent percentage worm load reduction $(\mathrm{P}<0.001)$. Carica papaya, showed highly reduction in worm counts $(60.3 \%$ and $68.2 \%)$ while Praziquantel $(92.8 \%)$, elevated immune responses and least time in destroying cercariae. The highest significant reduction in dead ova $(\mathrm{P}<0.001)$ was observed in group treated with EtOAc extract. The level of IgG1 and IgG2 was significantly reduced $(\mathrm{P}<0.001)$ than in groups treated with $C$. papaya crude extract, EtOAc extract or PZQ as compared to levels in untreated infected mice. While the level of $\mathrm{IgG} 1$ and $\mathrm{IgG} 2$ was insignificantly reduced in groups treated with $\mathrm{MeOH}$ extract or $\mathrm{BuOH}$ extract as compared to levels in untreated infected mice.

It was concluded from the results that the antischistosomal efficacy of the extracts was dependent being more potent in reducing both the worm burden and tissue egg load. The antishistosomal effect of $C$. papaya extracts was significantly higher in group treated with EtOAc extract. These findings supporting the potential use of $C$. papaya extracts in the management of schistosomiasis.

Keywords: Schistosomiasis, Carica papaya,Praziquantel-Antioxidant Potential.

\section{INTRODUCTION}

Carica papaya L. (papaya) is member of family Caricaceae and widely cultivated for its edible fruits (Canini et al., 2007). C. papaya is one of the most important fruit crops grown in the tropical and sub-tropical regions worldwide (Ali et al., 2011). C. papaya fruit is the major product from the tree and it is well known for its excellent taste, nutritive value and its digestive effects (Vuong et al., 2013). In the market, there is an increase interest of products derived from papaya in food and drug industry (Edith et al., 2016). Many scientific investigations showed that, $C$. papaya fruits extracts have many health benefits, such as reducing cardiovascular disease risk, anti-inflammatory, antioxidant, anticancer, antimicrobial activities and serving an immune-adjuvant for vaccine 


\section{Ibrahim Aly et al.}

therapy (Otsuki et al., 2010; Schweiggert et al., 2012; Galang et al., 2016). C. papaya phytochemical studies showed the presence of biologically and pharmacologically active constituents such as carotenoids, phenolic acids, flavonoids, and vitamin C (Ray et al., 2011). Considering the vast potentiality of plants as sources for anthelminthic drugs with reference to antiscistosomal agents, a systematic investigation was undertaken to screen the antischistosomal activities (in vivo) from dried seeds of Carica papaya. Their methanol and aqueous extracts were evaluated for antischistosomal properties against Schistosoma mansoni (Mokua John Mose et al., 2013). Several studies on methods used in extracting $C$. papaya materials from different parts of the plant were highlighted. Extracts from different parts of $C$. papaya plant have shown protective effects against many diseases such as intestinal worms infection and different types of wounds. Extracts also showed positive effects when used as antiparasitic, antiseptic, antimicrobial, antiinflammatory, antihyper-lipidemic, antihypertensive and antidiabetic (Abd ElGadir et al., 2013). The in vivo antiprotozoal activity of crude $C$. papaya seeds extract and its main components against Trypanosoma cruzi infective forms (blood trypomastigotes and amastigotes), during the acute phase of the disease was evaluated by (Matilde et al., 2014). PZQ still not reaching the majority of those who most need it due to its high cost and there is possibility of drug resistance, hence need for alternatives (Muchika et al., 2011). PZQ remains the only antibilharzial drug effective against the four main schistosomes pathogenic to man (Ali et al., 2011; Chen Hung and Chen Bing, 2012). Although it has been reported that PZQ has minimal side effects (Lin Long and Harnly 2010; Simirgiotis et al., 2009). Control of schistosomiasis using PZQ at a population level faces some problems. Resistance to PZQ has been recently induced in schistosomes by laboratory selection (Fallon and Doenhoff, 1994). Reduced cure rates and failure of treatment after PZQ have been reported in Senegalese, Kenyan and Egyptian patients PZQ still not reaching the majority of those who most need it due to its high cost and there is possibility of drug resistance, hence need for alternatives. The main aim of this study was to carry out a phytochemical analysis of $C$. papaya fruit mehanolic extract using HPLC-ESI-MS technique and evaluating the antischistosomal properties of $C$. papaya fruit extracts against Schistosoma mansoni as well as their antioxidant potential.

\section{MATERIALS AND METHODS Plant material}

Carica papaya fruits were purchased from local market, Giza, Egypt in May 2015. The voucher plant sample was characterized by Prof. Dr. Wafaa Amer, Professor of plant taxonomy, Faculty of Science, Cairo University. The voucher specimen has been deposited in medicinal chemistry laboratory, Theodor Bilharz Research Institute. The fruits of $C$. papaya were cut to small pieces, dried in the shade, finely powdered with an electric mill, and the dry powder was kept for the extraction process.

\section{Extraction and fractionation process}

Finely powdered $C$. papaya fruits (700 g) were extracted with 4 liters of $85 \%$ $\mathrm{MeOH}$ at room temperature. $85 \% \mathrm{MeOH}$ extract was filtrated and concentrated to dryness under reduced pressure using a rotatory evaporator (BUCHI, Switzerland) for three times, then it was defatted with petroleum ether, and the aqueous defatted $\mathrm{MeOH}$ extract was subjected to fractionation using dichloromethane $\left(\mathrm{CH}_{2} \mathrm{Cl}_{2}\right)$, ethyl 


\section{Antischistosomal and antioxidant protective role of Carica papaya fruit extracts against Schistosoma mansoni}

acetate (EtOAc) and butanol $(\mathrm{BuOH})$, respectively. The three fractions were concentrated to dryness with a rotatory evaporator. The methanolic extract and the three fractions were kept away from any moisture.

\section{In vitro study}

\section{In vitro antischistosomal bioassay screening}

Schistosoma mansoni worms were obtained from the Schistosoma Biological Supply Center (SBSC) at Theodor Bilharz Research Institute (TBRI), Giza, Egypt. The antischistosomal assay was carried out using method described by Metwalley (2015). S. mansoni worms were washed several times in sterile RPMI-1640 media (Cutilab) (pH 7.5, with HEPES $20 \mathrm{mM}$ and supplemented with penicillin $(100 \mathrm{U} / \mathrm{mL})$, sterptomycin $(100 \mathrm{mg} / \mathrm{mL})$, and $10 \%$ fetal calf serum. In $35 \mathrm{~mm}$ diameter $(35 \times 10$ $\mathrm{mm})$ polystyrene petri dish, 10 adult $S$. mansoni worms were cultured in $10 \mathrm{~mL}$ sterile RPMI-1640 media with descending concentrations of plant extracts and oil $(500,250$ and $125 \mathrm{ug} / \mathrm{mL})$ then incubated in a humid $5 \% \mathrm{CO} 2$ shaking incubator (SSI10R Large Refrigerated Incubator Shaker, Germany) at $37{ }^{\circ} \mathrm{C}$ for $24 \mathrm{hrs}$. In parallel, the adult worms were cultured in RPMI-1640 media containing 10\% DMSO (served as solvent control). The efficacy of different concentrations of plant extracts, mortality, viability and shrinking of worms, was observed using a stereomicroscope at different time intervals including 1,3 and $24 \mathrm{hrs}$ of incubation.

\section{Animals}

Six to eight week old male albino mice of the CD1 mice (weight $24 \pm 2 \mathrm{~g}$ ) bred and kept at the Schistosome biological supply center, Theodore Bilharz Research Institute Giza, Egypt (SBSP/TBRI). The mice were bred under environmentally controlled conditions, fed with a standard pellet diet and distilled water. Handling and treatment of animals were conducted according to internationally valid guidelines and ethical conditions adopted by Theodore Bilharz Research Institute.

\section{Doses}

Crude or purified extracts were administered in doses of $4 \mathrm{~g} / \mathrm{Kg}$ body weight daily for 45 days in a standard pelleted diet containing $24 \%$ protein, $4 \%$ fat and about $4-$ $5 \%$ fiber according to. Praziquantel was administered in a dose of $500 \mathrm{mg} / \mathrm{kg}$ body weight on two successive days after 45 days of infection.

\section{Parasites}

S. mansoni cercariae were obtained from Schistosome biological supply center, TBRI, and infection was performed directly after shedding from Biomophlaria alexandrina snails.

\section{Experimental Groups}

A batch of 70 mice was divided into six groups as follow:

Group 1: Normal healthy control (10 mice).

Group 2: Infected control group (10 mice). Mice were infected by the subcutaneous (s.c.) injection of 100 S. mansoni cercariae/mouse.

Group 3: Infected treated group (10 mice). Mice were infected by (s.c.) injection of $100 \mathrm{~S}$. mansoni cercariae/mouse and treated by oral administration with crude Carica papaya fruits $(4 \mathrm{~g} / \mathrm{kg})$ start from 7 th day p.i. to the end of experiment.

Group 4: Infected treated group (10 mice). Mice were infected by (s.c.) injection of 100 


\section{Ibrahim Aly et al.}

S. mansoni cercariae/mouse and treated by oral administration with $\mathrm{MeOH}$ extract $(4 \mathrm{~g} / \mathrm{kg})$ start from $7^{\text {th }}$ day p.i. to the end of experiment.

Group 5: Infected treated group (10 mice). Mice were infected by (s.c.) injection of 100 S. mansoni cercariae/mouse and treated with EtOAc extract $(4 \mathrm{~g} / \mathrm{kg})$ start from 7 th day p.i. to the end of experiment.

Group 6: Infected treated group (10 mice). Mice were infected by (s.c.) injection of 100 $S$. mansoni cercariae/mouse and treated with $\mathrm{BuOH}$ extract $(4 \mathrm{~g} / \mathrm{kg})$ start from 7 th day p.i. to the end of experiment

Group 7: Infected treated group (10 mice). Mice were infected by (s.c.) injection of 100 $S$. mansoni cercariae/mouse and treated twice at 6 weeks post-infection (p.i.) with $500 \mathrm{mg} / \mathrm{kg}$ PZQ. All mice were sacrificed at 8 weeks post-infection and subjected to the following parameters.

\section{Parasitological Criteria}

1. Worm burden:

Adult worms were harvested by hepatic and intestinal perfusion 6,8 , and 16 weeks after infection according to the method described by Duvall \& Dewitt (1967).

2. Tissue egg load (liver andintestine)

The number of eggs per gram tissue (liver and intestine) was studied according to the procedure by (Cheever, 1968).

\section{Percentage egg developmental stages "Oogram Pattern":}

The percentages of immature, mature, and dead ova in the small intestines were computed from a total of 100 eggs per intestinal segment and classified according to the categories previously defined by (Pellegrino,1962).

\section{Immunological Parameters:}

Determination of anti-Schistosomal immunoglobulin subclasses $\operatorname{IgG} 1, \operatorname{IgG} 2$ and IgG4 were measured using indirect ELISA, based on the method of (Engval \& Perlman, 1971). ELISA microtiter plates were coated with $100 \mathrm{ul} /$ well of $30 \mathrm{ug} / \mathrm{ml}$ of soluble worm antigen. Sera were diluted 1:20 and anti-mouse IgG subclasses (Binding site, Birmingham, UK) were used at a dilution of 1:500. Absorbance at $492 \mathrm{~nm}$ was measured.

\section{Statistical analysis:}

The data were presented as mean standard error of the mean $(\mathrm{X} \pm \mathrm{SE})$. The means of the different groups were compared globally using the analysis of variance ANOVA. Data were considered significant if $\mathrm{p}$ values were less than 0.05 .

\section{Worm load:}

\section{RESULTS}

The worm burden and tissue egg load in the intestine and liver were calculated for each studied group (Table 1). In the infected control group, the total number of worms counted was $29.2 \pm 0.99$. Oral administration of crude extract of Carica papaya, $\mathrm{MeOH}$ extract, EtOAc extract or $\mathrm{BuOH}$ extract of $C$. papaya $(100$ $\mathrm{mg} / \mathrm{kg}$ ) to mice after infection reduced the total worm burden to $11.6 \pm 1.44(60.3 \%$ reduction), $17.1 \pm 0.29$ (38.7\% reduction) and $9.3 \pm 1.21(68.2 \%$ reduction $)$ and 13.8 $\pm 2.09(52.7 \%$ reduction $)$, respectively whereas, administration with $500 \mathrm{mg} / \mathrm{kg}$ PZQ on two consecutive days at six weeks post-infection reduced the total worm burden to $2.1 \pm 0.03$ (92.8\% reduction). Oral administration of crude extract of $C$. papaya, $\mathrm{MeOH}$ extract, EtOAc extract or $\mathrm{BuOH}$ extract of $C$. papaya $(100 \mathrm{mg} / \mathrm{kg})$ to mice after infection reduced egg load both in the intestine and liver to $(51.7 \%$ \& $50.9 \%$ reduction), (33.7\% \& $33.5 \%$ reduction), $(40.2 \% \& 71.9 \%$ reduction $)$ and $(43.9 \%$ \& $66.5 \%$ reduction), respectively. Whereas, administration with $500 \mathrm{mg} / \mathrm{kg}$ PZQ on two 


\section{Antischistosomal and antioxidant protective role of Carica papaya fruit extracts against Schistosoma mansoni}

consecutive days at six weeks post-infection reduced the egg load both in the intestine and liver to $(96 \%$ \& $95.6 \%$ reduction). (Table 1, Fig.1).

Table 1: Worm burden and tissue egg load in mice treated with crude andsoluble

fractions of $C$. papaya.

\begin{tabular}{|c|c|c|c|c|c|c|}
\hline \multirow[b]{2}{*}{ Animal group } & \multirow{2}{*}{$\begin{array}{c}\text { Mean no. of } \\
\text { worms + SEM }\end{array}$} & \multirow[b]{2}{*}{$\begin{array}{c}\% \\
\text { reduction }\end{array}$} & \multicolumn{4}{|c|}{ Mean No of Ova Count + SEM/g tissue } \\
\hline & & & Intestine & $\begin{array}{c}\% \\
\text { reduction }\end{array}$ & Liver & $\begin{array}{c}\% \\
\text { reduction }\end{array}$ \\
\hline Infected control & $29.2 \pm 0.99$ & & $17839 \pm 1981$ & & $6519 \pm 704$ & \\
\hline \multicolumn{7}{|c|}{ Treated group } \\
\hline Crude extract & $11.6 \pm 1.44$ & 60.3 & $8619 \pm 168$ & 51.7 & $3198 \pm 29$ & 50.9 \\
\hline $\mathrm{MeOH}$ extract & $17.9 \pm 1.91$ & 38.7 & $11829 \pm 443$ & 33.7 & 4332 & 37 \\
\hline Crude extract & $11.6 \pm 1.44$ & 60.3 & $8619 \pm 168$ & 51.7 & $3198 \pm 29$ & 50.9 \\
\hline $\mathrm{BuOH}$ extract & $13.8 \pm 2.09$ & 52.7 & $9998 \pm 274$ & 43.9 & $2183 \pm 31$ & 66.5 \\
\hline \multicolumn{2}{|c|}{ PZQ } & $2.1 \pm 0.03$ & $92.8 \%$ & $793 \pm 99$ & $96 \%$ & 287 \\
\hline
\end{tabular}

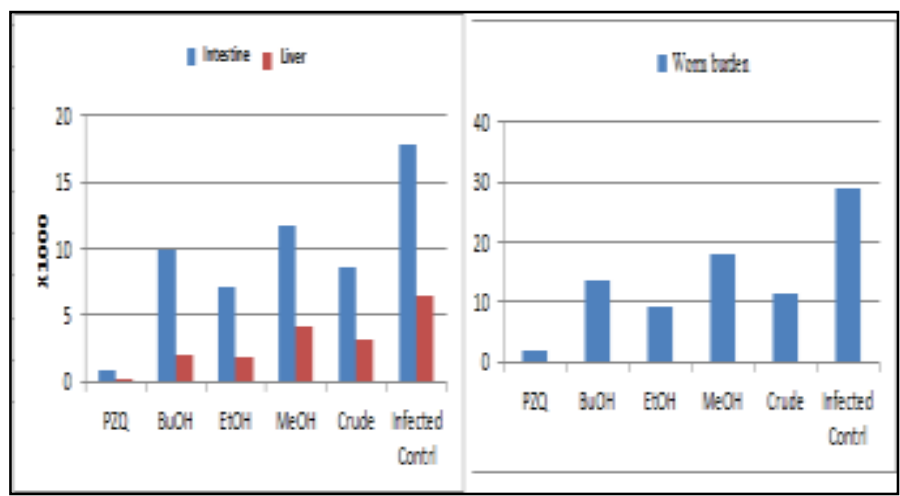

Fig. 1. Worm burden and tissue egg load in mice treated with crude and soluble fractions of $C$. papaya.

The results obtained in the current study showed a highly significant reduction $(\mathrm{P}<0.001)$ in the mean number of worms in infected and treated with EtOAc extract group IV and crude extract of Carica papaya II compared to the infected untreated group. Also, the current study showed a moderate significant reduction $(\mathrm{P}<0.05)$ in the mean number of worms in group treated with $\mathrm{MeOH}$ extract and in group treated with $\mathrm{BuOH}$ extract compared to the infected untreated group.

\section{Oogram pattern:}

The percent of immature ova was in significantly difference in all treated groups than the infected untreated one. While the percent of dead ova was $(11.6 \%, 17.2$, $27.1 \% \& 10.7)$ in the groups treated with crude extract of $C$. papaya, $\mathrm{Me} \mathrm{OH}$ extract, EtOAc extract or $\mathrm{BuOH}$ extract of $C$. papaya respectively. The highest significant reduction in dead ova $(\mathrm{P}<0.001)$ was observed in group treated with EtOAc extract (Table 2 , Fig. 2). 


\section{Ibrahim Aly et al.}

Table 2: Egg developmental stages (oogram) of infected mice administrated with crude and soluble fractions of C. papaya.

\begin{tabular}{|c|c|c|c|}
\hline \multirow{2}{*}{ Animal Group } & \multicolumn{2}{|c|}{ Oogram pattern ( \% ova) } \\
\cline { 2 - 4 } & Immature & Mature & Dead \\
\hline Infected control & $55.8 \pm 3.8$ & $39.1 \pm 2.6$ & $5.1 \pm 0.3$ \\
\hline Crude extract & $59.6 \pm 2.9$ & $28.8 \pm 3.7$ & $11.6 \pm 0.09$ \\
\hline MeOH extract & $49.9 \pm 3.1$ & $32.9 \pm 2.9$ & $17.2 \pm 0.1$ \\
\hline EtOAc extract & $52.1 \pm 4.2$ & $20.8 \pm 2.3$ & $27.1 \pm 0.32$ \\
\hline BuOH extract & $61.5 \pm 3.3$ & $.8 \pm 1.127$ & $10.7 \pm 1.1$ \\
\hline PZQ & $\mathbf{2 2 . 0} \pm \mathbf{0 . 3}$ & $\mathbf{8 . 9} \pm \mathbf{0 . 2}$ & $\mathbf{6 9 . 1} \pm \mathbf{4 . 9}$ \\
\hline
\end{tabular}

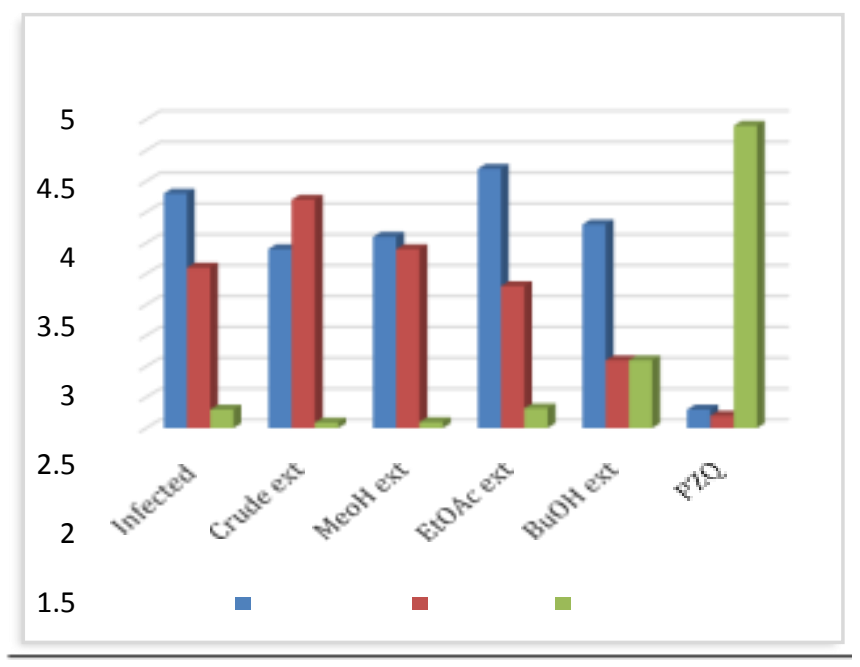

Fig. 2. Egg developmental stages (oogram) of infected mice administrated with crude and soluble fractions of $C$. papaya

\section{Immunological Parameters:}

Figure (3) showed the level of sera immunoglobulin subclasses $\mathrm{IgG} 1, \mathrm{IgG} 2$ and IgG4 in samples of mice infected with $S$. mansoni. The level of IgG1 and IgG2 was significantly reduced $(\mathrm{P}<0.001)$ than in groups treated with Carica papaya crude extract, EtOAc extract or PZQ as compared to levels in untreated infected mice. While the level of IgG1 and IgG2 was insignificantly reduced in groups treated with $\mathrm{MeOH}$ extract or $\mathrm{BuOH}$ extract as compared to levels in untreated infected mice. In regard to the level of IgG4 there is no any significant difference between all treated groups as compared to levels in untreated infected mice. 


\section{Antischistosomal and antioxidant protective role of Carica papaya fruit extracts against} Schistosoma mansoni

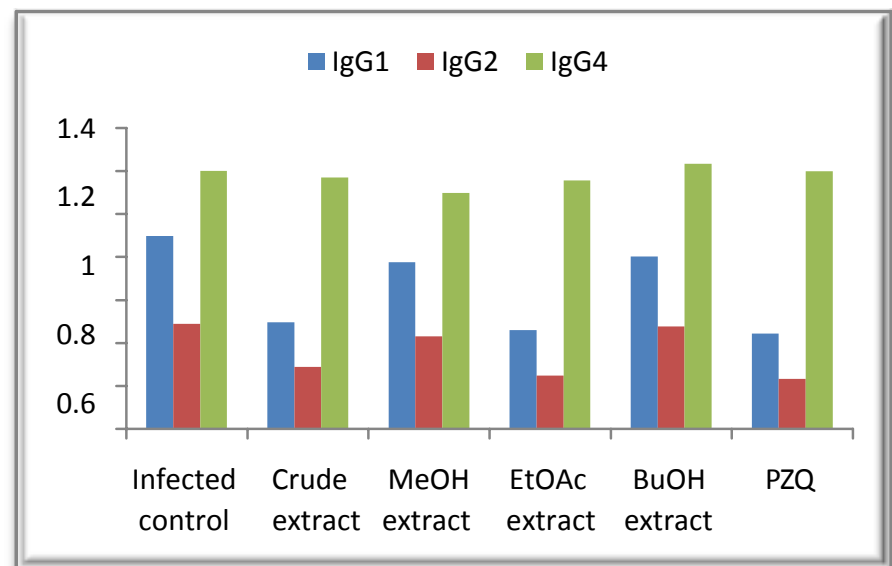

Fig. 3. Level of sera immunoglobulin subclasses IgG1, IgG2 and IgG4 in samples of mice infected with $S$. mansoni administrated with crude and soluble fractions of $C$. papaya..

\section{DISCUSSION}

Control of helminthiasis has therefore been the center of focus in biomedical research since time immemorial. Both the medical and veterinary professions have tried to control helminthiasis by administration of synthetic drugs (Sebuguzi, 2000). The anthelmintic property of plants is dependent on numerous substances that are found in them. These could be alkaloids, sugars, saponins, aromatic oils, resins and other medicinally useful chemicals (Lejoly1996). The milky juice of C. papaya contains proteolytic ferments, which together with papain have successfully been used as an anthelmintic agent for the treatment of Ascariasis, Trichuriasis, and ancylostomiasis (Watt, 1962).

This study agreed with Mokua et al. (2013) they showed that significant effect of the extracts was observed against schistosomal infected mice. Carica papaya methanol extract was found more effective against schistosomes recording less recovery while $C$. papaya aqueous extract recorded more recovery. The results of worm maturation in this study are comparable to those of other studies using the same mouse model confirming swiss mice as a good model for schistosome studies. The greatest loss of larval stages occurs during the migration through the lungs with relatively smaller losses during migration through the skin (WHO, 2002)

The antischistosomal properties of $\mathrm{C}$. papaya fruit extracts against Schistosoma mansoni as well as in vitro antischistosomal bioassay screening their antioxidant potential were evaluated.

Antischistosomal effects of crude Carica papaya (methanol or aqueous) extracts were studied patterns on immune response, worm recovery, gross pathology in vivo and cercaricidal killing in vitro of Schistosoma mansoni was observed.In the present study, $C$. papaya methanol extract exhibit the shortest time to kill cercariae compared to $C$. papaya aqueous extract, this is agree with (Muchika et al., 2011).

The maximum duration for the destruction of the cercariae in the four treatments; both aqueous and methanol treatments of $C$. papaya was 20 minutes in the lowest concentrations $(5 \mu \mathrm{g} / \mathrm{ml})$. Time of killing decreased with increase in concentrations to a maximum concentration (30 $\mu \mathrm{g} / \mathrm{ml})$. The speed, at which cercariae can penetrate skin and find a vascular portal, varies considerably. The maximum killing time (20 minutes) was very encouraging 


\section{Ibrahim Aly et al.}

because it is less than the time taken by most cercariae to locate and penetrate the host skin (Jordan,1993). A few cercariae can make this journey within five minutes (MCKerrow \&Salter 2002) in which they would have already been weakened or killed by the extracts. The ability of these extracts to destroy cercariae can be incorporated in an ointment to be applied by people before wading in water infested with schistosome infected snails.

In the present study, the level of IgG1 and IgG2 was significantly reduced $(\mathrm{P}<0.001)$ in groups treated with $C$. papaya crude extract, EtOAc extract or PZQ as compared to levels in untreated infected mice. While the level of IgG1 and IgG2 was insignificantly reduced in groups treated with $\mathrm{MeOH}$ extract or $\mathrm{BuOH}$ extract as compared to levels in untreated infected mice. Carica papaya, showed elevated immune responses and least time in destroying cercariae (Muchika et al., 2011).The elevated levels of IgG responses in infected-untreated control can be associated with a high worm burden leading to a high level of circulating parasite antigens many of which are not related to protection (Njoroge et al., 2010). This high IgG level did not confer protective immunity in infected-untreated control as demonstrated by the highest number of worm recovery. The $\mathrm{IgG}$ responses in Praziquantel were relatively high, and in this case, unlike the untreated control, it had the lowest worm burden and the lowest pathology. Praziquantel kills the worms directly and also, induces schistosomespecific immune response which reduces the worm burden further. This results in reduced pathology, as lower number of worms translates to lower egg production, and hence fewer granulomas (Muchika et al., 2011).Carica papaya methanol had lower IgG responses to both antigens as compared to aqueous extract, and lower worm counts, but pathology of both $C$. papaya extracts was similar. This high IgG response level seen in $C$. papaya and reduced gross pathology is supported by (Mojca- Henshaw et al., 2003) who reported that Carica seed extract has an immunostimulatory action which is illustrated in the ability to inhibit significantly the classical complementmediated haemolytic pathway.

\section{REFERENCES}

Abdel Elgadir, M. and Aisha, A. (2013). An in vitro evalution of films prepared from geltin- Carica papaya methanolc extract for wound healing. J. Drug Delivery, 5:233-238.

Ali, A.; Muhammad, M.T.M.; Sijam, K. and Siddiqui, Y. (2011). Effect of chitosan coatings on the physicochemical characteristics of Eksotika II papaya (Carica papaya L.) fruit during cold storage. Food Chemistry, 124:620-626.

Caninia, A.; Alesiania, D.; D’Arcangelo, G. andTagliatesta, P. (2007). Gas chromatography-mass spectrometry analysis of phenolic compounds from Carica papaya L leafe. J. Food Composition and Analysis, 20:584590.

Cheever, A.W. (1968). Conditions affecting the accuracy of potassium hydroxide digestion techniques for counting Schistosoma mansoni eggs in tissues. Bull. World Health Organ. 39:32833.

Chen Hung-Ju; Inbaraj, B.S. and Chen Bing-Huei (2012). Determination of phenolic acids and flavonoids in taraxacum formosanum kitam by liquid chromatography-tandem mass spectrometry coupled with a postcolumn derivatization technique.Int. J. Mol. Sci., 13:260-285. 


\section{Antischistosomal and antioxidant protective role of Carica papaya fruit extracts against Schistosoma mansoni}

Duvall, R.H.; and Dewitt, W.B. (1967). An improved perfusion teqchnique for recovering adult Schistosomes from laboratory animals. Am. J. Trop. Med. Hyg., 16: 483-486.

Edith, M.Q.; Calvache, Z.; Dora, I.R.; Iuan, D.R.; Sara, C.; Soto- De Leon; Milena, C.; Luisa, D.; Ricado, S.; Manuel, E.P. and Manuel, A.P. (2016). Chlamydia trachomatis Frequency in a Cohort of HPVInfected Colombian Women. PLOSONE|, 11(1): 1-14. DOI:10.1371/journal.pone.0147504 January 25,2016.

Engval. E. and Perlman, P. (1971). Enzymelinked immunosorbent assay (ELISA). Quantitative assayof immunoglobulin G. Immunochemistry, 8(9): 871-874.

Fallon, P.G. and Doenhoff, M.J. (1994). Drug-Resistant schistosomiasis: Resistance to Praziquantel and Oxaminquine induced in Schistosoma mansoni in mice is drug specific. Am. J. Trop. Med \& Hyg. 51(1):83-88

Galang, M.G.M.; Macabeo, A.; Patrick, G.; Chang, W.; Isobe, M. and Aguinaldo, M.M. (2016). Glucosides from the unripe fruit juice of Carica papaya Linn. (Caricaceae) cultivar 'Red Lady' with antioxidant activity. J. Functional Foods, 22:358-362.

Jordan, A.; Wust, P. and Fahling, H.(1993). Inductive heating of ferrimagnetic particles and magnetic fluids: Physical evaluation of their potential for hyperthermia. Int. J. Hyperthermia, 9:51-68.

Lejoly, J.; Polygeris-Bindeko, M.J. and Maes, F. (1996). Herbal Medicine In Health in Central Africa Since 1885. King Baudoum Foundation.
Lin, Long-Ze and Harnly, J.M. (2010). Identification of the phenolic components of Chrysanthemum flower (Chrysanthemum morifolium Ramat). Food Chemistry 120 :319326.

Matilde, J.; Karla, Y.A.; Antonio, O.; Salud, P. and Eugenia, G. (2014). In Vivo Antiprotozoal Activity of the chloroform extract from Carica papaya seeds against amastigote stage of Trypanosoma cruzi during indeterminate and chronic phase of infection. Evidence- Based complementary and Alternative Medicine, volume 1: pages458263.

MCKerrow J.H., Salter J. (2002): Invasion of skin by Schistosoma cercariae. Trend Parasitol. 2002; 18(5):193-5.

Metwalley, K.M. (2015). Assessment of the antischistosomal activity of some plant extracts against Schistosoma mansoni infection. World J. Medical Sci., 12 (2): 162-169.

Mojca- Henshaw, M.P.; Francisco, A.D.; De Guzman, F. and Tigno, X.T. (2003). Possible immunodulatory action of Carica papaya seed extract. Clin. Hemorheol. Microcirc. 29 (3-4):21929.

Mokua, J.M.; Helen, K.; Rebecca, W. and Dorcas, Y. (2013). Evaluating the antischistosomal activity of crude extracts of Carica Papaya against Schistosoma mansoni: the Interplay of Cellular and Humoral Immunity. J. Biomedical and Pharmaceutical Res., 2 (1):33-41.

Muchika, S.; Kutima, H.L.; Maranga, R.O. and Yole, D.S.(2011). AntiSchisosomal effects of Solanum incanum and Carica papaya crude extracts on the parasite Schistosoma 


\section{Ibrahim Aly et al.}

mansoni in vivo and in vitro. $\mathrm{J}$. Tropical Medicine (7):2.

Njoroge, G.N.; Kaibuil, M.; Njenga, P.K. and Odhiambo, P.O. (2010). Utilisation of priority traditional medicinal plants and local people's knowledge on their conservation status in arid lands of Kenya (Mwingi District). J. Ethnobiol. Ethnomed., 6: 22.

Otsuki, N.; Dang, N.H.; Kumagai, E.; Kondo, A.; Iwata, S. and Morimoto, C. (2010). Aqueous extract of Carica papaya leaves exhibits anti-tumor activity and immune-modulatory effects. J. Ethnopharmacol., 127:760-767.

Pellergrino, J.; Oliveira, C.A.; Faria J. and Cunha, A.S. (1962). New approach to the screening of drugs in experimental Schistosomiasis mansoni in mice. Am. J. Trop. Med. Hyg., 11:201-215.

Ray M. and Paul H. Moore (2011): Plant Genetics and Genoics: Crops and Models 10. ISBN 978.1-4614-80877(eBook).

Schweiggert, R.M.; Steingass, C.B.; Esquivel, P. and Carle R.(2012). Chemical and morphological characterization of Costa Rican papaya (Carica papaya L.) hybrids and lines with particular focus on their genuine carotenoid profiles. J. Agric. Food Chem., 60: 2577-2585.
Sebuguzi, F. (2000). Ethno veterinary medicine in Gomba county, Mpigi district: Use of medicinal plants by livestock farmers in the treatment of their animals. Undergraduate thesis, Faculty of Veterinary Medicine, Makerere University, Kampala.

Simirgiotis, M.J.; Caligari, P.D.S.; Schmeda- Hirschmann, G. (2009). Identification of phenolic compounds from the fruits of the mountain papaya Vasconcellea pubescens A. DC. grown in Chile by liquid chromatography-UV detection-mass spectrometry. Food Chemistry, 115:775-784.

Vuong, Q.V.; Hirun, S.; Roach, P.D.; Bowyer, M.C.; Phillips, P.A. and Scarlett, C.J. (2013). Effect of extraction conditions on total phenolic compounds and antioxidant activities of Carica papaya leaf aqueous extracts. Journal of herbal medicine 3: 104-111.

Watt, J. M. and Breyer-Brandwijk, M. G. (1962). Medicinal and Poisonous Plants of Southern and Eastern Africa. 2nd Edition, Livingstone, London, pp200-270.

World Health Organization (2002). Expert Committee. Prevention and control of schistosomiasis and soil transmitted helminthiasis. Geneva: WHO/CDS/2004.9 


\title{
Antischistosomal and antioxidant protective role of Carica papaya fruit extracts against Schistosoma mansoni
}

\author{
الاور الوقائي لمضادات البلهارسيا ومضادات الاكسدة لمستخلصات فاكهة البابيا ضد بلهارسيا مانسوني \\ ابراهيم علي 1، حنان طاهر 2،3 * ، فاتن الفقي3 3

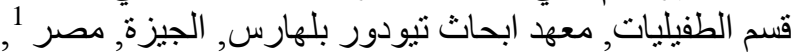

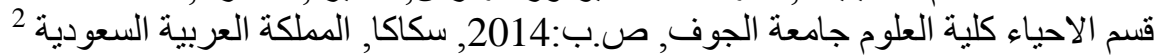

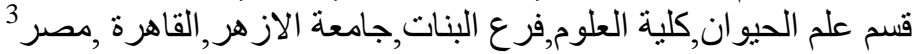 \\ * dr.h.taher@gmail.com
}

\begin{abstract}
المستخلص

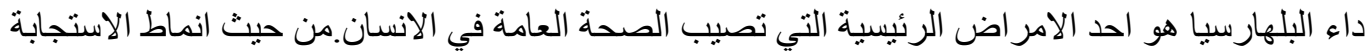

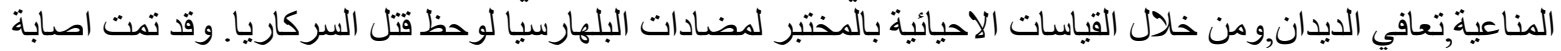

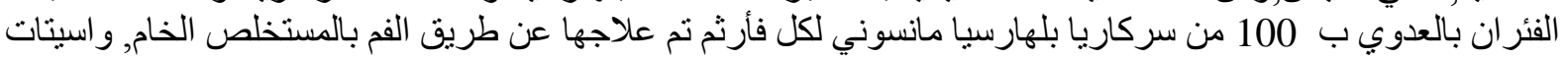

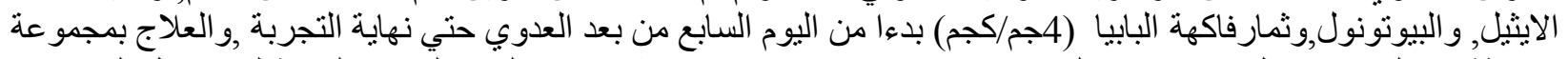

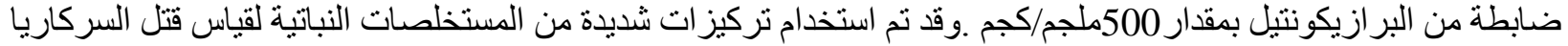

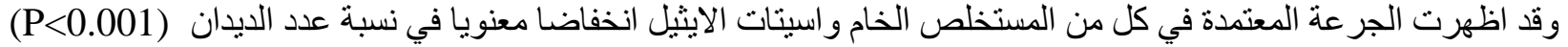
و واظهرت البابيا انخفاضا في عد الديدان مقداره

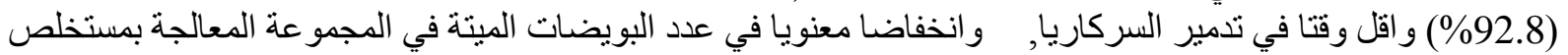

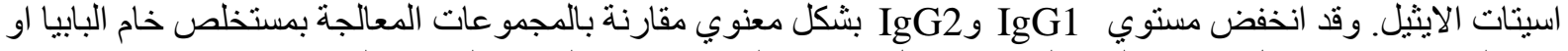

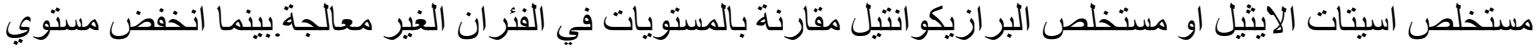

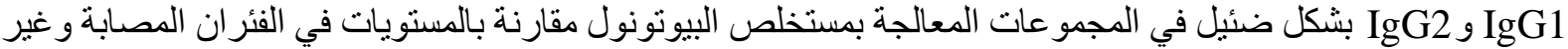

معالجة. وقد أتضح من النتائج ان استخدام مستخلصات البابيا فعال في ادارته كمضادات للبلهارسارسيا. الكلمات الدالة: داء البلهارسيا- البابيا-بر ازيكونتيل_مضادات الاكسدة المحتملة.
\end{abstract}

